\title{
Eletrolite leakage as a Technique to Diagnose Euphorbia heterophylla BIOTYPES RESISTANT TO PPO-INHIBITORS HERBICIDES ${ }^{1}$
}

\author{
Técnica do Extravasamento Eletrolítico para Diagnosticar a Resistência de Biótipos de \\ Euphorbia heterophylla a Herbicidas Inibidores da PROTOX
}

\author{
TREZZI, M.M. ${ }^{2}$, VIDAL, R.A. ${ }^{3}$, KRUSE, N.D. ${ }^{4}$, GUSTMAN, M.S. ${ }^{5}$, XAVIER, E. ${ }^{6}$, ROSIN, D. ${ }^{6}$ and \\ DEDORDI, G.F. ${ }^{6}$
}

\begin{abstract}
The action of herbicides that affect the integrity of cell membranes and cause leakage, like PPO-inhibitors, can be detected by measuring the electric conductivity (EC) of a solution in which the plant tissue target is incubated in the presence of herbicide. The objectives of this work were to confirm PPO resistance in a new Euphorbia heterophylla (EPHHL) biotype, and to compare the electrolyte leakage from $\mathrm{R}$ and $\mathrm{S}$ to PPO-inhibitors biotypes, using two different methods of incubation in a solution containing herbicides. One experiment was carried in greenhouse and three in laboratory, with a completely randomized design. In the greenhouse experiment, four biotypes of EPHHL were sprayed with seven rates of fomesafen to confirm resistance in suspected biotypes. Leaf disks from $\mathrm{R}$ and S EPHHL biotypes in the second and the third experiments and entire leaves in the fourth experiment were incubated in a solution containing PPO-inhibitors to subsequently determine EC of solution. The study confirmed the resistance to PPO-inhibitors in two EPHHL biotypes. There were no significant differences between $\mathrm{S}$ and $\mathrm{R}$ biotypes in the experiments with the incubation of leaf disks, but incubation of entire leaves of EPHHL S biotype showed higher EC when in a solution with fomesafen, in comparison to the $\mathrm{R}$ biotype. The results of this work are an indirect evidence that resistance to PPO-inhibitors is related to lower absorption of herbicide by the shoots and also to some kind of mechanism to cope with oxidative stress.
\end{abstract}

keywords: cell disruption, electrical conductivity, herbicide absorption, resistance mechanism, wild poinsettia.

\begin{abstract}
RESUMO - A ação de herbicidas que afetam a integridade das membranas celulares e causam extravasamento, como o inibidores da Protox, pode ser detectada através da medição da condutividade elétrica (CE) de uma solução em que tecidos da planta-alvo são incubados na presença de herbicida. Os objetivos deste trabalho foram confirmar a resistência a inibidores da Protox em um novo biótipo de Euphorbia heterophylla (EPHHL) do Brasil, e comparar o extravasamento eletrolitico em biótipos $R$ e S a inibidores da Protox, utilizando dois métodos diferentes de incubação em solução contendo herbicidas. Um experimento foi conduzido em casa de vegetação, etrês em laboratório, em delineamento inteiramente casualizado. No experimento em casa de vegetação, quatro biótipos de EPHHL foram pulverizados com sete niveis de fomesafen, para confirmar a resistência em biótipos suspeitos. No segundo eterceiro experimentos, discos foliares de biótipos de EPHHL R e S e, no quarto experimento, a folha inteira, foram incubados em solução contendo inibidores da Protox, para depois determinar a $C E$ da solução. O estudo confirmou a resistência aos inibidores da Protox em dois novos biótipos de EPHHL suspeitos. Em experimentos com incubação de discos foliares não houve diferenças significativas entre os biótipos $R$ e S. Mas, na incubação de folhas inteiras de EPHHL com fomesafen, o biótipo $S$ apresentou maior $C E$, em comparação ao biótipo $R$. Os resultados deste trabalho são uma evidência indireta de que a resistência aos inibidores da enzima Protox está relacionada à menor absorção de herbicidas pela parte aérea e também a algum mecanismo para fazer frente ao estresse oxidativo.
\end{abstract}

Palavras-chave: absorção de herbicidas, condutividade elétrica, extravasamento celular, leiteira, mecanismo de resistência.

Recebido para publicação em 1.9.2010 e aprovado em 16.2.2011.

2 Professor, Dr., Curso de Agronomia, Universidade Tecnológica Federal do Paraná - UTFPR, Campus Pato Branco, Via do Conhecimento, km 01, Caixa Postal 571, 85503-390 Pato Branco-PR, <trezzi@utfpr.edu.br>; ${ }^{3}$ Professor, PhD., Universidade Federal do Rio Grande do Sul - UFRGS, Porto Alegre-RS; ${ }^{4}$ Professor, Dr., Universidade Federal de Santa Maria - UFSM, Santa Maria-RS; ${ }^{5}$ Eng ${ }^{\mathrm{a}}-\mathrm{Agr}^{\mathrm{a}}$., Cooperativa CAMISC, Mariópolis-PR; ${ }^{6}$ Acadêmicos do Curso de Agronomia, UTFPR.

Planta Daninha, Viçosa-MG, v. 29, n. 3, p. 655-662, 2011 


\section{INTRODUCTION}

The weed resistance (R) to herbicides is one of the most discussed topics in weed science and, globally, it is one of the biggest issues among those involved in the agricultural activity. However, the real magnitude of weed resistance to herbicides in the Brazilian agriculture is not fully known and, in general, main actions occur only after the confirmation of cases of $R$. While a wide range of knowledge has been added since the first confirmed case of R in Brazil in 1996 (Christoffoleti et al., 1996), great progress should occur, mainly regarding the monitoring of suspected areas, improvement of diagnostic methods, identification of the $\mathrm{R}$ mechanism, and development and dissemination of prevention methods.

Worldwide, only five $\mathrm{R}$ to $\mathrm{PPO}$ inhibitors weed biotypes have been found in three different species: Ambrosia artemisiifolia (USA), Amaranthus rudis (USA) and Euphorbia heterophylla (Brazil) (Heap, 2010). The first case of $\mathrm{R}$ to PPO inhibitors weed was confirmed in a pigweed (Amaranthus rudis) biotype in Kansas, USA (Shoup et al., 2003). In 2004, in soybean areas located in the Southwest region of the state of Paraná, in Brazil, two $E$. heterophylla (EPHHL) biotypes that were not controled with the herbicides imazethapyr (ALS inhibitor) and fomesafen (PPO inhibitor) when applied at the recommended doses (Trezzi et al., 2005, 2006) were identified. In Brazil, the largest use of PPO-inhibiting herbicides is found in soybeans and beans, as well as in horticulture and reforestation (Merotto Jr. \& Vidal, 2001). In such crops, PPO inhibitors constitute a very important group of herbicides because there are limited numbers of mechanisms of action that can be used for weed control. Therefore, the existence of PPO$\mathrm{R}$ biotypes in Brazil is an important problem to be investigated.

Both tolerance and resistance to PPO-inhibiting herbicides in several plant species occur through many mechanisms, such as: fast metabolic process and limited translocation in peanuts (Eastin, 1971); fast metabolic process (Dayan et al., 1997) and high concentration of the PPO enzyme in mitochondria (Warabi et al., 2001) in soybean; mutation at the PPO nuclear gene that confers changes on the enzymes that act in the mitochondria and chloroplasts of Amaranthus tuberculatus (Patzoldt et al., 2006).

Preliminary investigation with EPHHL biotypes PPO- $R$ in Brazil suggested that metabolism was not the mechanism of $R$ in one of these biotypes (Trezzi et al., 2009a). PPO-inhibiting herbicides can be absorbed either through the weeds leaves or roots. But, for the acifluorfen, fomesafen, lactofen, flumiclorac, flumioxazin and carfentrazone herbicides, the absorption is predominantly foliar (Merotto Jr. \& Vidal, 2001). Investigations conducted by our research group reported that lower levels of control in the $\mathrm{R}$ biotype compared to the susceptible (S) were observed when fomesafen was applied to EPHHL shoots. But, when this herbicide was applied to the soil, there was no significant difference between the biotypes. These results strongly suggest that the mechanism of $R$ is related to absorption of PPO inhibitors by the shoots in EPHHL (Trezzi et al., 2009b).

After the PPO enzyme is inhibited by this group of herbicides, there is a huge formation of free radicals, followed by lipid peroxidation and destruction of the plasma membrane (Duke et al., 1991). The action of the herbicides affect the integrity of the cell membranes and cause electrolytic leakage, which can be detected by measuring the electric conductivity of a solution in which the target plant tissue is incubated in the presence of herbicide (Vanstone \& Stobbe, 1978). Electrolyte leakage can result from biotic, abiotic and xenobiotic stresses (Vanstone \& Stobbe, 1978; Blum et al., 1981; Liu \& Huang, 2000). Measurement of electrical conductivity was used to identify acifluorfen sensitivity in Amaranthus rudis biotypes (Li et al., 2004) and for assessment of the oxidative stress coming from synergism from the mixtures of a PSII inhibitor herbicide and a carotenoid synthesis inhibitor (Kruse et al., 2006).

The objectives of this study were: (a) to confirm PPO resistance in E. heterophylla biotypes; (b) to compare the electrolyte leakage between PPO-inhibitors $\mathrm{R}$ and $\mathrm{S}$ biotypes, using two different methods of incubation in a solution containing herbicides, in order to evaluate this technique as a tool for detection 
of PPO R in E. heterophylla. Furthermore, this work may assist in identifying the $R$ mechanism in this new biotype.

\section{MATERIAL AND METHODS}

Four experiments were conducted at the Agronomy School of Universidade Tecnologica Federal do Paraná - UTFPR (Federal Technological University of Paraná), located in Pato Branco, state of Paraná, Brazil, in a completely randomized design with three replications.

Experiment 1 was conducted in a greenhouse with a $4 \times 7$ factorial design. The first factor consisted of four populations of $E$. heterophylla (EPHHL) and the second factor was the rates of fomesafen herbicide $(0,22.5$, $50,100,200,400$ and $\left.800 \mathrm{~g} \mathrm{ha}^{-1}\right)$. In this experiment, biotype number 23, from the city of Vitorino, state of Paraná, was used. PPO R has been previously confirmed in this biotype (Trezzi et al., 2005). Other biotypes used in the experiment included a $\mathrm{S}$ biotype from the city of Renascença, state of Paraná, and two suspected R biotypes detected in 2008 in the city of Bom Sucesso do Sul, state of Paraná. The seeds of these last two populations were collected within the same field, but separately, because the plants had different hair stem characteristics (hairy or hairless).

For this experiment, all biotypes plants were grown in pots with a capacity of $1,000 \mathrm{~cm}^{3}$ of soil. When the plants had reached the two true-leaf growth stage, fomesafen herbicide was sprayed over the shoots using a $\mathrm{CO}_{2}$ backpack sprayer with 110.02 nozzles and water volumes of $180 \mathrm{~L} \mathrm{ha}^{-1}$.

Experiments 2 to 4 were conducted in the lab using the method adapted from Kruse (2002). In these experiments, electrolyte leakage was evaluated with the use of leaf disks to verify whether the $R$ to herbicides is expressed in the absence, at least in part, of barriers to herbicides uptake. Experiments 2 and 3 were arranged in a $2 \times 9$ factorial design. The first factor consisted of the EPHHL biotypes (the biotype number $23(\mathrm{R})$ and $\mathrm{S}$ ) and the second factor was nine concentrations of each PPOinhibiting herbicide (fomesafen for experiment 2 and flumiclorac for experiment 3) $5 \mathrm{~mm}$ diameter disk samples were removed from plants leaves that were grown as described previously. 40 disks were used for each replication to evaluate electric conductivity.

Experiment 4, which was arranged in a $3 \times 9$ factorial design, evaluated electrolyte leakage using intact leaves to determine whether the $\mathrm{R}$ to herbicides is expressed in the presence of barriers to uptake. The first factor consisted of the EPHHL biotypes (the biotype number $23(\mathrm{R})$, the hairy biotype from the city of Bom Sucesso do Sul, state of Paraná (R) and the biotype from the city of Renascença, state of Paraná (S)). The second factor consisted of nine fomesafen concentrations. 16 whole leaves were collected for each replication in order to evaluate electric condutivity. Special care was taken to avoid any damage to the leaves during their transport to the laboratory. After the removal of the leaves, the region of insertion of the petiole on the stem was sealed with paraffin.

After the removal, the leaf discs (experiments 2 and 3 ) and intact leaves (experiment 4) were immersed in $20 \mathrm{~mL}$ of incubation solution in Petry dishes with $9 \mathrm{~cm}$ diameter and $1.5 \mathrm{~cm}$ height. The incubation solution consisted of distilled water with $1 \%$ $\left(\mathrm{pv}^{-1}\right)$ sucrose and $1 \mathrm{mM}$ MES NaOH buffer $(2$ (N-morpholin) ethanesulphonic acid), with $\mathrm{pH}$ adjusted to 6.5. This solution was used for incubation of the dilutions of fomesafen (experiments 2 and 4 ) and flumiclorac (experiment 3). In experiments 2 and 3 (leaf discs), the concentrations of herbicide used were: $0,20,40,80,160,320,640,1,280$ and 2,560 micromolar. In experiment 4 (intact leaves), the following concentrations were used: $0,88,160,320,640,1,280,2,560,5,120$ and 10,240 micromolar. Higher herbicide concentrations were used in experiment 4 , compared to 2 and 3 , because less electrolyte leakage was expected when using the whole leaf, compared to the use of leaf discs.

Discs/leaves were incubated in herbicide solution for 24 hours in the absence of light and 36 hours in the presence of light at the temperature of $24 \pm 0.5{ }^{\circ} \mathrm{C}$. After the incubation periods, the solutions with and without discs/leaves and the herbicides were placed in test tubes and electric conductivity was measured through a condutivimeter with a platinum electrode and expressed in 
$\mu \mathrm{mho} \mathrm{cm}^{-1}$. In the fourth experiment, the measurement of conductivity was expressed as a function of the relative weight of green tissue $\left(\mu \mathrm{mho} \mathrm{cm}^{1} \mathrm{~g}^{1}\right)$, because the areas of leaf tissue placed in each Petri dish were not the same.

The results were submitted to analysis of variance and the $F$ test was used to evaluate the significance of main factors and interaction between factors. The relationship between herbicide efficacy and fomesafen rates was adjusted by polynomial regression. Likewise, the regressions between electric conductivity and herbicide concentration were adjusted through the logistic equation of four parameters (Seefeldt et al., 1995), using the Sigmaplot software.

\section{RESULTS AND DISCUSSION}

The dose-response curves for the four E. heterophylla (EPHHL) biotypes indicate that the levels of control were much higher for the plants from the S biotype than for the other three biotypes. The levels of control for the plants from the biotypes 23 and Bom Sucesso do Sul (hairless) reached maximum values of $20 \%$, when evaluated at 7 DAA, whereas the highest level of control of the $\mathrm{S}$ biotype was $95 \%$. Similar trends were maintained up to the 21 DAA (Figure 1). These results are consistent with those obtained by Gelmini et al. (2001) and Trezzi et al. (2005), who found high efficacy in control of EPHHL S populations with the use of fomesafen. The efficacy of fomesafen to control susceptible weeds depends on several factors, including application on weeds at early stage of development (Rizzardi et al., 2004; Ruas et al., 2005) and lack of water stress (Zanatta et al., 2008).

Fomesafen had limited effect on both biotypes from Bom Sucesso do Sul, hairy and hairless (suspect R), and biotype 23 (Trezzi et al., 2005, 2006, 2009a, b). These results confirm that all three biotypes are $\mathrm{R}$ to fomesafen (Figure 1). Also, there were no significant differences between the control of the two biotypes from Bom Sucesso do Sul (hairy and hairless), which means that the morphological differences observed at the field are not associated with increased EPHHL tolerance to fomesafen herbicide. EPHHL plants collected in a soybean crop in Londrina, state of Paraná, have been separate through RAPD markers into two major groups which differed mainly on shape of the leaf and density of branches (Vasconcelos et al., 2000). However, the pubescence character of the stem could not distinguish groups very clearly, unlike leaf shape and density of branches.

For all fomesafen concentrations, the electric conductivity in the herbicide solution with leaf discs of S plants was higher when compared to R plants from biotype 23 (Figure 2).
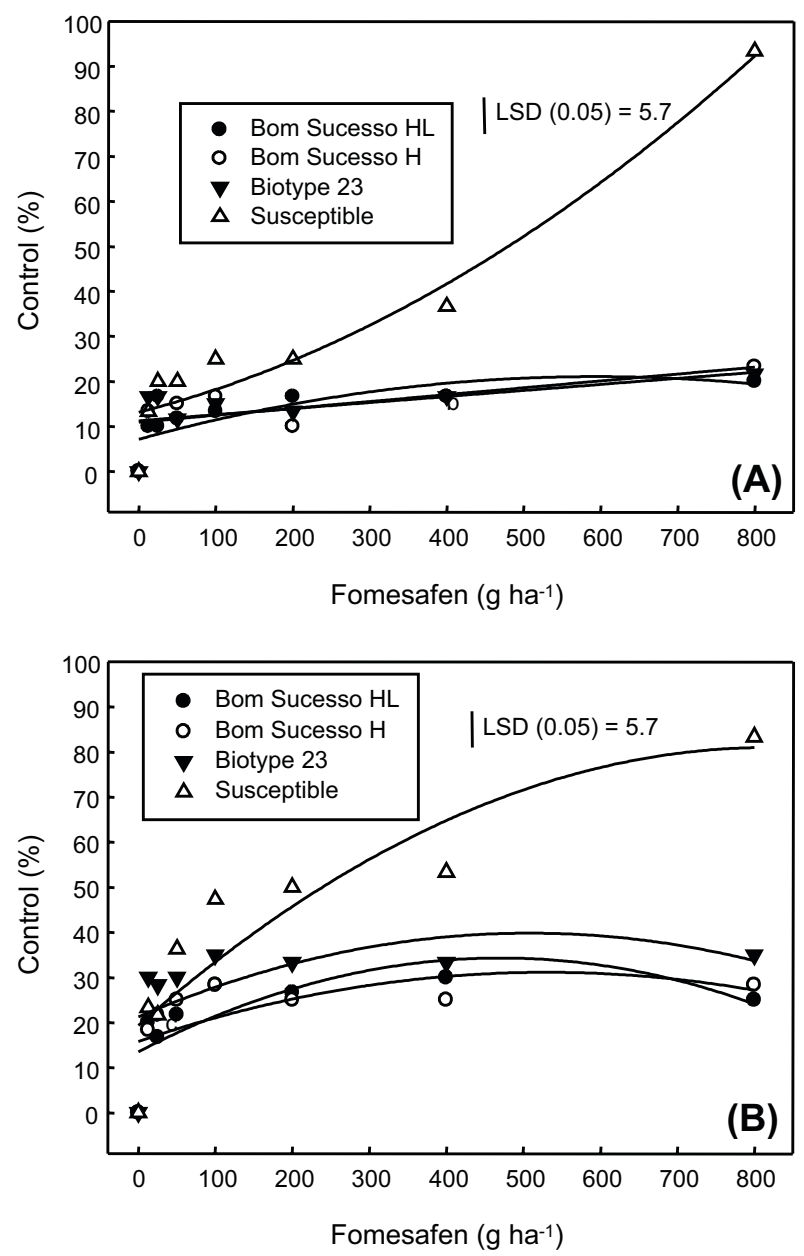

LSD 0.05 vertical bar indicates value for significant differences $(\mathrm{P}<0.05)$ according to $\mathrm{t}$ test.

Figure 1 - Dose-response curves to fit the relationship between fomesafen rates and levels of control of four E. heterophylla biotypes from the Southwestern region of Paraná State, Brazil, evaluated at 7 (a), and 21 (b) days after the herbicide application. 
However, the difference between them was not due to the presence of fomesafen, since the results without fomesafen (zero concentration) also showed differences between $\mathrm{S}$ and $\mathrm{R}$ biotypes, similar to those obtained with different levels of fomesafen (Figure 2).

In the experiment evaluating relationship between flumiclorac concentrations and electric conductivity, significant differences between $\mathrm{S}$ and $\mathrm{R}$ biotypes were only detected at herbicide concentrations of $0,1,250$ and 2,500 micromolar (Figure 3). At low concentrations of flumiclorac, differences in electric conductivity between biotypes were lower when compared to control without herbicide.

The results of leaf discs incubation with fomesafen and flumiclorac indicate that the higher electrolyte leakage for the $\mathrm{S}$ biotype, when compared to the $R$, is a inherent feature of this biotype. The differences in the electrolyte leakage between $\mathrm{S}$ and $\mathrm{R}$ biotypes, caused by oxidative stress, can be observed even without the presence of the herbicide. In other words, the background level of oxidative stress is higher in the $\mathrm{S}$ than in the $\mathrm{R}$ biotypes. The subsequent leakage of cell contents follows parallels from the background level and do not increase with the addition of

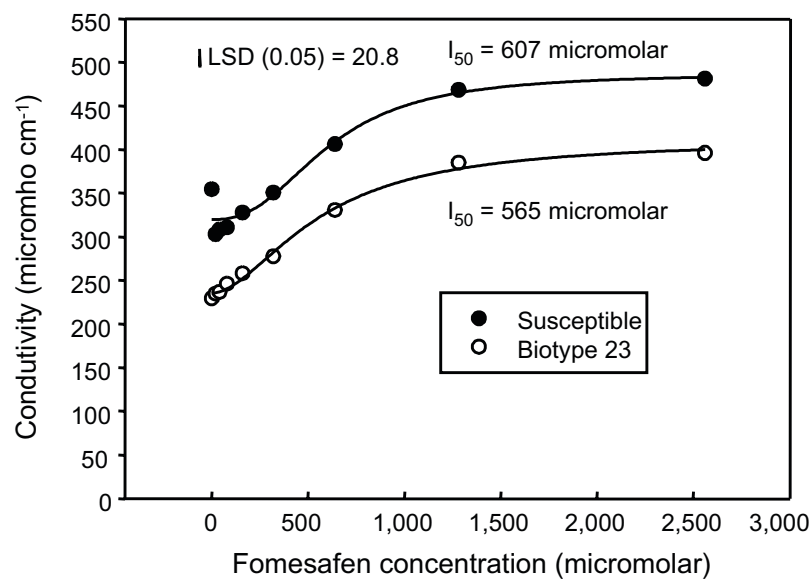

LSD 0.05 vertical bar indicates value for significant differences $(\mathrm{P}<0.05)$ according to $t$ test. $\mathrm{I}_{50}$ indicates the level of fomesafen to $50 \%$ increase in the electrolyte conductivity of the solution.

Figure 2 - Effect of concentrations of fomesafen on the electric conductivity of solutions incubated with leaf discs of E. heterophylla susceptible and resistant to PPO-inhibitors. fomesafen and flumiclorac herbicides (Figures 3 and 4).

This is corroborated by examining the values of $I_{50}$, the dose required to increase the electric conductivity by $50 \%$ (Figures 2 and 3 ). When incubated with fomesafen, the value of $\mathrm{I}_{50}$ for the PPO-R biotype was lower (565 micromolar) than for the $\mathrm{S}$ biotype

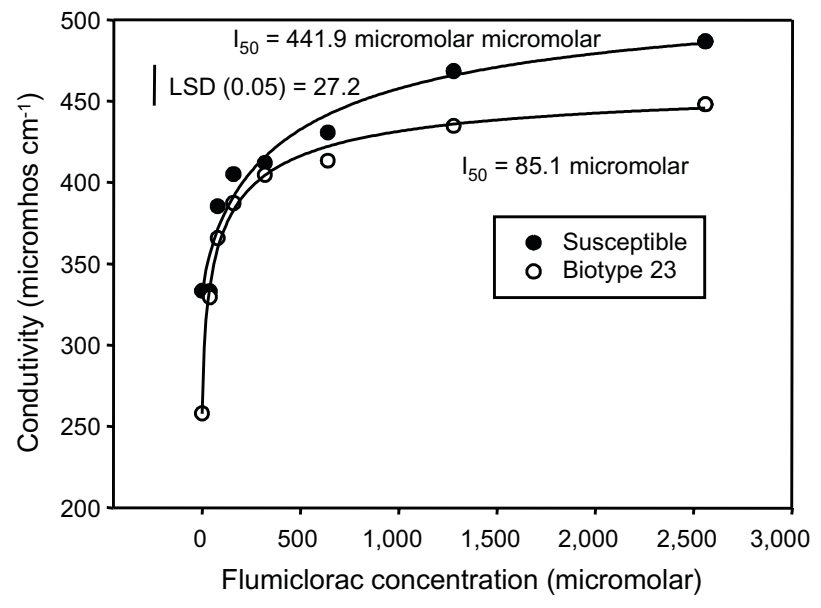

LSD 0.05 vertical bar indicates value for significant differences $(\mathrm{P}<0.05)$ according to $t$ test. $\mathrm{I}_{50}$ indicates the level of fomesafen to $50 \%$ increase in the electrolyte conductivity of the solution.

Figure 3 - Effect of flumiclorac concentrations on the electric conductivity of solutions incubated with leaf discs of E. heterophylla susceptible and resistant to PPO-inhibitors.

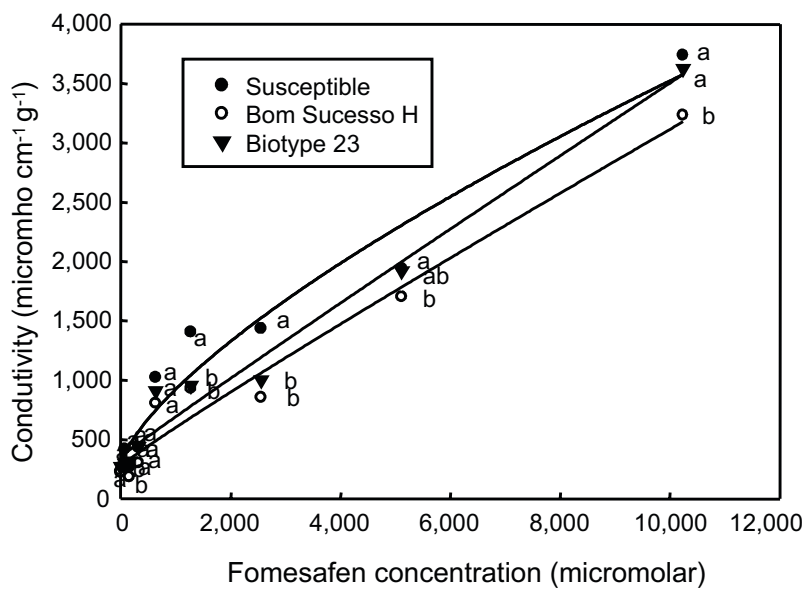

Different letters indicates significant differences $(\mathrm{P}<0.05)$ according to LSD test.

Figure 4 - Effect of fomesafen concentrations on the electric conductivity of solutions incubated with intact leaves of three E. heterophylla biotypes. 
(607 micromolar). The results also indicate that the $R$ biotype had a lower $I_{50}$ value (85.1 micromolar) for flumiclorac as in comparison to the $\mathrm{S}$ biotype (441.9 micromolar).

Electrolite leakage data were used to calculate the resistance factors $\left(R F=I_{50} R /\right.$ $\mathrm{I}_{50} \mathrm{~S}$ ) and yielded 0.93 and 0.19 for fomesafen and flumiclorac, respectively. Factors of resistance lower than 1.0 indicate lack of resistance. But this result is in disagreement with the obtained FR results for these biotypes using whole plant assays and with herbicides applied to the shoots. In these experiments, the obtained RF using the herbicide efficacy data ranged between 39 and 62 (Trezzi et al., 2005) and between 1.4 and 2.1 (Trezzi et al., 2009b).

Electrolyte leakage can result from biotic, abiotic and xenobiotic stresses. Fischer (2008) suggests there is an association between the resistance of weeds to biotic and abiotic stresses and resistance to PPO-inhibitors. This would occur because these processes are generators of free radicals in the plants. Thus, a strategy of defense against free radicals caused by biotic or abiotic stress that were also present would be effective for protection against free radical-generating herbicides, such as PPO-inhibitors.

At this point of the investigation, we suspected that the damaging of the leaves when getting the leaf disk samples was causing the high oxidative stress background. Besides that, tissue disruption produced during disk extraction of the leaf discs may have facilitated the herbicide penetration inside the leaf. Our previous work strongly suggested the $R$ to be dependent of herbicide penetration inside the leaves. For instance, it was demonstrated that when herbicides are used in post-emergence, there are maximum differences between $\mathrm{R}$ and $\mathrm{S}$ biotypes (Trezzi et al., 2009b), probably because of barriers to their penetration into cells, such as the intact cuticle of the leaves. When sprayed to the soil, however, the differences in herbicide efficacy between $\mathrm{R}$ and $\mathrm{S}$ plants almost disappeared (Trezzi et al., 2009b).

Comparison of electrolyte leakage between $\mathrm{S}$ and $\mathrm{R}$ to acifluorfen Amaranthus rudis biotypes using different times of incubation with the herbicide was performed by Li et al.
(2004). They only found an increase in leakage at the presence of acifluorfen in the S biotype, but not in $\mathrm{R}$ biotype. However, the values of conductivity in the control without herbicide obtained with the $\mathrm{R}$ biotype were lower than those obtained with the S biotypes, as occurred in the experiments from Figures 2 and 3.

The results from Figure 2 and 3 also suggest that the mechanism of resistance to PPO-inhibiting herbicides in the evaluated biotype is not due to a change in the PPO enzyme site of action, because the electrolite leakage with increased herbicide concentration palalled the results at the untreated leaf disks.

In the next experiment, the electric conductivity was determinated in intact leaves (Figure 4). Significant differences were found between the biotypes only for some concentrations of fomesafen. For instance, at the concentration of 640 micromolar of fomesafen, no differences among the three biotypes of EPHHL were found in electric conductivity for intact leaves. But, at concentrations of 1,280 and 2,560 micromolar of fomesafen, the incubation of S biotype leaves resulted in higher electrolyte leakage than those of R biotypes 23 and from Bom Sucesso do Sul. For the herbicide, at concentration of 5,120 micromolar, higher electrolyte leakage was found for the S biotype than for the biotype from Bom Sucesso do Sul, whereas biotype 23 had an intermediary electrolyte leakage. For the herbicide at concentration of 10,240, higher electrolyte leakage was found for the $\mathrm{S}$ and number 23 biotypes than for the biotype from Bom Sucesso do Sul (Figure 4).

It is also important to consider that the values of electric conductivity of the control without herbicide for the three biotypes did not differ, unlike what occurred in the experiment with leaf discs. Thus, this result strongly suggests that the physical process of tissue disruption by cutting the leaf discs generates oxidative stress and that the $R$ biotype probably had stronger mechanisms to reduce oxidative stress than the $\mathrm{S}$ biotype, thus presenting lower electric conductivity resulting from the incubation of the leaf discs in absence of the herbicide (Figures 2 and 3). The lack of differences in electrolyte leakage between the $S$ and $R$ biotype in the 
process of incubation of intact leaves (Figure 4) indicates that, in the absence of physical stress, biotypes maintain similar levels of conductivity between them. However, in the experiment with leaf discs, with increase of herbicide concentration, the fact that the oxidative stress generated for the $\mathrm{S}$ biotype has not increased at higher rates than those generated for the $R$ biotype is not explained.

The fact that, at some concentrations, fomesafen resulted in electrolyte leakage above the one observed after incubation of intact leaves of $\mathrm{S}$ biotype (Figure 4), is an indication that this biotype exhibits lower barriers to the penetration of PPO-inhibiting herbicides than the $R$ biotypes, as there were no significant differences between biotypes due to increased levels of fomesafen and flumiclorac in the incubation of leaf discs (Figures 2 and 3). This result is in line with those obtained in another experiment (Trezzi et al., 2009b), which showed higher differences between the herbicide efficacy in $\mathrm{S}$ and $\mathrm{R}$ biotypes after the application of fomesafen in the shoots compared to its application in the soil (pre-emergence), where the cuticle is less developed.

Overall, the results of this work indicate that measurement of electrolytic conductivity is a useful tool for the detection of resistance to PPO-inhibitors and that it helps in the investigation of the mechanism of resistance pertaining to this group of herbicides. There is strong evidence that herbicide resistance to PPO-inhibitors is related to lower absorption of herbicide by the shoots and also to some mechanism to cope with oxidative stress.

\section{ACKNOWLEDGMENTS}

This study was funded by Fundação Araucária de Desenvolvimento Científico e Tecnológico do Paraná (Araucária Foundation) and Conselho Nacional de Desenvolvimento Científico e Tecnológico - CNPq (National Council for Scientific and Technological Development).

\section{LITERATURE CITED}

BLUM, A.; EBERCON, A. Cell membrane stability as a measure of drought and heat tolerance in wheat. Crop Sci., v. 21, p. $43-47,1981$.
CHRISTOFFOLETI, P. J. et al. Imidazolinone resistant Bidens pilosa biotypes in the brazilian soybean areas. In: MEETING OF THE WSSA. Abstracts... Norfolk: 1996 p. 10 .

DAYAN, F. E. et al. Soybean (Glycine max) cultivar differences in response to sulfentrazone. Weed Sci., v. 45, p. 63-641, 1997

DUKE, S. O. et al. Protoporphyrinogen oxidase-inhibiting herbicides. Weed Sci., v. 39, p. 465-473, 1991.

EASTIN, E. F. Fate of fluorodifen in resistant peanut seedlings. Weed Sci., v. 19, p. 261-265, 1971.

FISCHER, A. Mecanismos de resistencia: las bases para definir estratégias. In: RIOS, A.; FERNÁNDEZ, E. (Ed.). SEMINÁRIO INTERNACIONAL VIABILIDADE DEL GLIFOSATO EN SISTEMAS PRODUCTIVOS SUSTENTABLES. Anais... Colônia: INIA, 2008. CDROM.

GELMINI, G. A. et al. Resistência de biótipos de Euphorbia heterophylla aos herbicidas inibidores da ALS utilizados na cultura da soja. Bragantia, v. 60, n. 1, p. 93-99, 2001.

HEAP, I. International survey of resistant weeds. Available at: http://www. weedsciencie.org/in. asp. Acessed Aug. 2010.

KRUSE, N. D. Análise da associação de metribuzin e clomazone como modelo para o estudo do sinergismo entre herbicidas. 2002. 135f. Tese (Doutorado em Fitotecnia) - Universidade Federal do Rio Grande do Sul, Porto Alegre, 2002.

KRUSE, N. D. et al. Estresse oxidativo em girassol (helianthus annuus) indica sinergismo para a mistura dos herbicidas metribuzin e clomazone. Planta Daninha, v. 24, n. 2, p. 379-390, 2006.

LI, J. et al. Physiological basis for resistance to diphenyl ether herbicides in common waterhemp (Amaranthus rudis).

Weed Sci., v. 52, p. 333-338, 2004.

LIU, X.; HUANG, B. Heat stress injury in relation to membrane peroxidation in creeping bentgrass. Crop Sci., v. 40, p. 503-510, 2000.

MEROTTO, Jr., A.; VIDAL, R. A. Herbicidas inibidores de PROTOX. In: VIDAL, R. A.; MEROTTO Jr., A. (Eds.). Herbicidologia. Porto Alegre: Edição do Editores, 2001. p. 69-86.

PATZOLDT, W. L. et al. A codon deletion confers resistance to herbicides inhibiting protoporphyrinogen oxidase. Proc. National Acad. Sci. United States Am., v. 103, p. 12329-12334, 2006.

Planta Daninha, Viçosa-MG, v. 29, n. 3, p. 655-662, 2011 
RIZZARDI, M. A. et al. Aspectos gerais do manejo e controle de plantas daninhas. In: VARGAS, L.; ROMAN, E. S. (Eds.) Manual de manejo e controle de plantas daninhas. Bento Gonçalves: Embrapa Uva e Vinho, 2004. p. 105-144

RUAS, R. A. A. et al. Aplicação do fomesafen via água de irrigação por aspersão no controle de Euphorbia heterophylla. Planta Daninha, v. 23, n. 3, p. 501-507, 2005.

SEEFELDT, S. S.; JENSEN, S. E.; FUERST, E. P. Log-logistic analysis of herbicide dose-response relationships. Weed Technol., v. 9, p. 218-227, 1995.

SHOUP, E. D.; AL-KHATIB, K.; PETERSON, D. E. Common waterhemp (Amaranthus rudis) resistance to protoporphyrinogen oxidase-inhibiting herbicides. Weed Sci., v. 51, p. 145-150, 2003.

TREZZI, M.M. et al. Multiple resistance of acetolactate synthase and protoporphyrinogen oxidase inhibitors in Euphorbia heterophylla biotypes. J. Environ. Sci. Health part B, v. 40, p. 101-109, 2005.

TREZZI, M.M. et al. Bioensaios para identificação de biótipos de Euphorbia heterophylla com resistência múltipla a inibidores da ALS e da PROTOX. Planta Daninha, v. 24, n. 3, p. 563-571, 2006.
TREZZI, M. M.; NUNES, A.; PORTES, E. D. S. Interação entre inseticida organofosforado e herbicidas inibidores da PROTOX e sua implicação na resistência de Euphorbia heterophylla. Sci. Agric., v. 10, p. 423-428, 2009a.

TREZZI, M.M. et al. Local de absorção de fomesafen como mecanismo de resistência em biótipo de Euphorbia heterophylla resistente aos inibidores da PROTOX Planta Daninha, v. 27, p. 139-148, 2009b.

VANSTONE, D. E.; STOBBE, E. H. Root uptake, translocation, and metabolism of nitrofluorfen and oxyfluorfen by fababeans (Vicia faba) and green foxtail (Setaria viridis). Weed Sci., v. 26, p. 389-392, 1978.

VASCONCELOS, M. J. V. et al. Variabilidade genética de biótipos de leiteiro de Londrina/PR. Planta Daninha, v. 18 n. 2, p. 285-292, 2000.

ZANATTA, J. F. et al. Teores de água no solo e eficácia do herbicida fomesafen no controle de Amaranthus hybridus. Planta Daninha, v. 26, n. 1, p. 143-155, 2008.

WARABI, E. et al. Resistance of a soybean cell line to oxyfluorfen by overproduction of mitochondrial protoporphyrinogen oxidase. Pest Manag. Sci., v. 57, n. 8, p. 743-748, 2001. 